\title{
MENINGKATKAN PEMBELAJARAN PUKULAN FOREHAND LOB BULUTANGKIS DENGAN MENGGUNAKAN PART AND WHOLE METHOD PADA PESERTA DIDIK KELAS VIII E SMPN 1 WINONGAN KABUPATEN PASURUAN
}

\author{
Ahmad Hasan Walinono \\ Eko Hariyanto \\ Fahrial Amiq \\ Fakultas Ilmu Keolahragaan Universitas Negeri Malang \\ E-mail: hasan.fikum@gmail.com
}

\begin{abstract}
This research was conducted to improve the students' forehand lob skill. After reviewing some references, the researcher decided to apply part and whole method. This research was Classroom Action Research (CAR) conducted in two cycles and done in three meetings. The research subject were the students of VIII E of junior high school 1 Winongan 2014/2015 academic year. There were 37 students consisted of 30 males and 7 females. After the action was applied, the students who were able to show correct practice were as follows; (a) aspect of handgrip 34 (91.8\%), (b) aspect of ready attitude $32(86.4 \%)$, (c) aspect of arm attitude $33(89.1 \%)$, (d) aspect of foot attitude $32(86.7 \%)$, (e) aspect of the direction of suttlecock $31(83.7 \%)$. Based on the result of the research, the researcher suggests the teacher to use part and and whole method as the alternative teaching method in order to improve the students' forehand lob skill.
\end{abstract}

Keywords: badminton, forehand lob, part and whole method

\begin{abstract}
Abstrak: Tujuan penelitian ini dilakukan yaitu untuk meningkatkan keterampilan pukulan forehand lob. bulutangkis. Setelah mempelajari beberapa referensi, peneliti memutuskan untuk menggunakan part and whole method. Penelitian ini merupakan Penelitian Tindakan Kelas (PTK) yang dilakukan selama 2 siklus, masing-masing siklus terdiri dari 3 kali pertemuan. Subjek penelitian ini adalah peserta didik kelas VIII E SMPN 1 Winongan Kabupaten Pasuruan sejumlah 37 peserta didik yang terdiri dari 30 peserta didik laki-laki dan 7 peserta didik perempuan. Setelah diterapkannya tindakan, peserta didik mampu mempraktikkan dengan benar adalah sebagai beriut: (a) aspek pegangan raket $34(91,8 \%)$, (b) aspek sikap siap 32 (86,4\%), (c) aspek sikap lengan $33(89,1 \%)$, (d) aspek sikap kaki $32(86,4 \%)$, (e) arah shuttlecock 31 (83,7\%). Berdasarkan hasil penelitian tersebut, peneliti menyarankan agar part and whole method dapat dijadikan sebagai metode pembelajaran alternatif guna meningkatkan pukulan forehand lob bulutangkis.
\end{abstract}

Kata Kunci: bulutangkis, forehand lob, part and whole method.

Agar prestasi belajar peserta didik mengalami peningkatan yang maksimal, maka peran pendidik di lapangan menjadi sangat penting pada saat proses pembelajaran pendidikan jasmani olahraga dan kesehatan berlangsung, pendidik harus mampu menyampaikan materi pembelajaran dengan jelas dan sistematis sehingga tujuan dari pendidikan nasional dapat tercapai.
Badan Standar Pendidikan Nasional (BNSP) (2006:702) menerangkan bahwa pendidikan jasmani merupakan bagian integral dari pendidikan secara keseluruhan, bertujuan untuk mengembangkan aspek kebugaran jasmani, keterampilan gerak, keterampilan berfikir kritis, keterampilan sosial, penalaran, stabilitas emosional, tindakan moral, aspek pola hidup sehat, dan pengenalan ling- 
kungan bersih melalui aktivitas jasmani, olahraga dan kesehatan terpilih dan direncanakan secara sistematis dalam rangka mencapai tujuan pendidikan nasional. Sedangkan UNESCO dalam "International Charter of Physical Education and Sport" (1978) menjelaskan bahwa pendidikan jasmani adalah suatu proses pendidikan seseorang sebagai individu atau anggota masyarakat yang dilakukan secara sadar dan sistematik melalui berbagai kegiatan jasmani dalam rangka meningkatkan kemampuan dan keterampilan jasmani, pertumbuhan kecerdasan dan pembentukan watak.

Berdasarkan paparan yang telah diuraikan, maka dapat ditarik kesimpulan bahwa pendidikan jasmani merupakan suatu proses pendidikan seseorang sebagai individu yang dilakukan secara sadar dan sistematis untuk meningkatkan keterampilan jasmani, pertumbuhan kecerdasan, dan pembentukan watak.

Pembelajaran pendidikan jasmani olahraga dan kesehatan yang dilaksanakan SMPN 1 Winongan Kabupaten Pasuruan pada kelas VIII E semester gasal tahun ajaran 2014/2015 berdasarkan pada Kurikulum Tingkat Satuan Pendidikan (KTSP), materi yang diajarkan yaitu: (1) Permainan dan olahraga, (2) Aktivitas pengembangan, (3) Aktivitas ritmik, (4) Senam, (5) Aktivitas air, (6) Pendidikan luar sekolah, (7) Kesehatan.

Cabang olahraga dalam pembelajaran pendidikan jasmani olahraga dan kesehatan yang diajarkan di SMPN 1 Winongan berdasarkan Kurikulum Tingkat Satuan Pendidikan (KTSP) sangat banyak.Salah satu diantaranya adalah permainan bulutangkis dengan SK 1. Mempraktikkan berbagai teknik dasar permainan dan olahraga dan nilai-nilai yang terkandung di dalamnya, dan KD 1.2. Mempraktikkan variasi dan kombinasi teknik dasar salah satu permainan dan olahraga bola kecil lanjutan dengan koordinasi yang baik serta nilai kerjasama, toleransi, percaya diri, keberanian, menghargai lawan, bersedia berbagi tempat dan peralatan.

Mencermati pokok Kurikulum Tingkat Satuan Pendidikan (KTSP) pada poin yang pertama, maka di SMPN 1 Winongan Kabupaten Pasuruan juga melaksanakan pembelajaran pendidikan jasmani olahraga dan kesehatan dengan materi teknik dasar permainan dan olahraga bulutangkis pukulan forehand lob.

Permainan bulutangkis merupakan salah satu cabang olahraga yang dimainkan oleh dua orang pemain yang saling berlawanan untuk nomor (tunggal) atau empat orang pemain yang saling berlawanan untuk nomor (ganda) dengan menggunakan raket sebagai alat pemukul dan shuttlecock sebagai objek yang dipukul. Permainan ini merupakan cabang olahraga yang sudah mendunia dengan ditandai cabang olahraga ini mulai dipertandingkan dalam olimpiade di Barcelona pada tahun 1992 (Susanto, 2006:15). Permainan bulutangkis dimainkan di atas sebidang lapangan permainan yang berukuran panjang $13,40 \mathrm{~m}$ dan lebar 6,10 $\mathrm{m}$ dengan dibatasi oleh jaring atau (net) setinggi $1,55 \mathrm{~m}$ dari lantai yang membagi bidang permainan yang sama luasnya. Bulutangkis merupakan olahraga raket yang paling cepat sehingga memerlukan pergerakan dan reaksi yang cepat. (Yogesh, 2011:245).

Garis lapangan mempunyai ketebalan garis $38 \mathrm{~mm}$ (1.5 inci) dan harus berwarna kontras terhadap warna lapangan. Warna untuk garis lapangan yang disarankan adalah putih atau kuning. Sedangkan permukaan lapangan yang disarankan terbuat dari kayu atau bahan sintesis yang lunak.

Permainan bulutangkis pada dasarnya permainan memukul dan menangkis shuttlecock ke daerah lapangan lawan yang dibatasi oleh net dengan menggunakan raket sebagai alat untuk memukul. Aksan (2012:14) menerangkan bahwa bulutangkis adalah olahraga raket yang dimainkan oleh dua orang (tunggal) atau dua pasangan (ganda) yang mengambil posisi berlawanan di bidang lapangan yang terbagi menjadi dua oleh sebuah jaring atau net. Para pemain meraih angka dengan memukul shuttlecock permainan berupa shuttlecock dengan raket melewati net dan jatuh di bidang permainan lawan. Tiap pemain atau pasangan hanya boleh memukul shuttlecock sekali sebelum shuttlecock melewati net. Sebuah reli berakhir jika shuttlecock menyentuh lantai atau menyentuh tubuh seorang pemain". 
Ahmad Hasan Walinono, Meningkatkan Pembelajaran Pukulan Forehand Lob Bulutangkis Dengan Menggunakan Part And Whole Method Pada Peserta Didik Kelas Viii E Smpn 1 Winongan, Kabupaten Pasuruan

Tujuan dari permainan bulutangkis adalah memperoleh angka dan memenangkan pertandingan dengan menyeberangkan shuttlecock di daerah permainan lawan. Seperti yang dijelaskan oleh Husdarta (2010:16), “adapun tujuan permainan bulutangkis adalah menyeberangkan shuttlecock melewati net dan menjatuhkannya di daerah lawan. Namun, harus berusaha menahan shuttlecock dari lawan upaya tidak jatuh di lapangan sendiri".

Prinsip dasar permainan bulutangkis adalah satu kali memukul shuttlecock sebelum jatuh di daerah lapangan sendiri dengan memukul atau mengembalikan shuttlecock ke daerah lawan dengan melintas net, baik di pukul dengan keras atau pelan untuk memaksa lawannya bergerak atau berlari di area lapangannya. Adapun tujuan dasar permainan bulutangkis adalah memenangkan suatu pertandingan dengan mendapatkan 20 poin dalam setiap set, apabila terjadi kedudukan 20 sama, otomatis akan terjadi deuce 2 (permainan akan berakhir pada poin 22). Deuce 2 otomatis diberlakukan apabila kemudian terjadi lagi kedudukan sama (permainan akan berakhir dengan selisih 2 poin). Bila masih terjadi kedudukan 29 sama, tidak lagi diberlakukan deuce (permainan akan berakhir pada poin 30).

Ada beberapa macam keterampilan dasar yang harus dimiliki oleh setiap pemain dalam permainan bulutangkis. Husdarta (2010:19-23) mengatakan bahwa keterampilan dasar olahraga bulutangkis dapat dibagi dalam empat bagian yaitu: "(1) cara memegang raket (grips), (2) sikap siap (stand and ready potition), (3) gerak langkah, (4) teknik pukulan".

- Cara memegang raket (Grips)

Permainan bulutangkis sering disebutsebut sebagai olahraga yang banyak menggunakan pergelangan tangan.Karena itu, benar atau tidaknya teknik memegang raket menentukan kualitas pukulan seseorang. Teknik pegangan yang benar menentukan pada hasil pukulan seorang pemain. Sebagaimana dijelaskan oleh Aksan (2012 :53), "pegangan raket yang benar adalah dasar untuk mengembangkan dan meningkatkan semua jenis pukulan dalam permainan bulutangkis". Maka dari itu, jika teknik pegangan sejak awal sudah salah, maka sulit sekali setiap pemain untuk meningkatkan kualitas permainan.

Menurut Poole (2011:18), ada beberapa teknik memegang raket yaitu: (a) pegangan forehand, teknik pegangan forehand disebut juga pegangan pistol (pistol grip) dan mirip dengan keadaan tangan yang sedang berjabat tangan. Teknik saat melakukannya adalah peganglah leher raket dengan tangan sebelah kiri, dengan bidang raket tegak lurus tubuh anda. Tempatkan tangan kanan anda pada tali raket (senar) dan geser ke arah pergelangan raket sehingga tengah-tengah dari bagian bawah telapak tangan berada pada ujung pegangan raket. Pegangan raket harus terletak menyilang pada telapak tangan dan jari-jari tangan kanan anda. Jari telunjuk harus sedikit terpisah dari jari-jari seperti hendak menarik pelatuk pistol. Ibu jari melingkar wajar pada sisi kiri dari pegangan raket. Letak jari-jari agak renggang antara yang satu dengan yang lainnya, (b) pegangan backhand, teknik pegangan ini mirip seperti pegangan Forehand. Perbedaannya adalah letak ibu jari yang dipindahkan dari kedudukan melingkar sisi pegangan raket (untuk forehand) menjadi tegak di sudut kiri atas dari pegangan tersebut (untuk backhand), (c) pegangan frying pan grip (pegangan panci penggoreng), teknik pukulan ini biasanya dipakai untuk melakukan dan mengembalikan pukulan servis, serta saat melakukan permainan net pada permainan yang membutuhkan pukulan-pukulan pendek. Teknik memegang raket yaitu pegang dan angkat dengan bidang raket dengan bidang raket sejajar dengan tubuh. Dalam keadaan seperti itu anda merasa seperti memegang panci penggoreng. Ujung pegangan raket menonjol kurang lebih sepanjang $2.54 \mathrm{~cm}$ (1 inci) di bawah telapak tangan.

- Sikap siap (stand and ready potition)

Pada dasarnya teknik ini mudah untuk dilakukan, apabila seorang pemain pada saat melakukan teknik dasar sikap siap ini kurang tepat akan mengakibatkan gerakan menjadi kurang efisien dan merugikan sang pemain yang melakukannya. Sikap siap dalam permainan bulutangkis penting dikuasai karena memungkinkan seorang pemain bisa bergerak cepat mengambil kemana arah shuttlecock yang datang ke penjuru lapangan permainan. "Sikap dan posisi di 
lapangan harus sedemikian rupa, sehingga pemain dapat secara cepat bergerak ke segala penjuru lapangan permainan" Alhusin (2007:30).

Sedangkan hal yang harus diperhatikan pada sikap dan posisi di lapangan menurut Alhusin (2007:30-31) adalah: (a) berdirilah sedemikian rupa, sehingga berat badan tetap berada pada kedua kaki dan keseimbangan tubuh terjaga, (b) tekuk kedua kaki, berdiri pada ujung kaki, sehingga posisi pinggang tetap tegak dan rileks. Kedua kaki terbuka selebar bahu dengan posisi kaki sejajar, atau salah satu kaki diletakkan di depan kaki lannya, (c) posisikan kedua lengan dengan siku bengkok di samping badan, sehingga lengan bagian atas yang memegang raket tetap bebas bergerak, (d) peganglah raket sedemikian rupa, sehingga kepala (daunnya) raket berada lebih tinggi dari kepala kita (kepala pemain), (e) waspada dan memperhatikan jalannya shuttlecock selam permainan berlangsung.

Posisi siap adalah "Berdirilah dengan kaki sejajar, dalam posisi terbuka lebih besar sedikit dari bahu anda. Lutut anda menekuk dan berat badan berada pada bagian telapak kaki sebelah muka, dekat pangkal ibu jari.Raket biasanya dipegang mengarah ke atas dan kepala raket sedikit berada pada sisi backhand dari tubuh anda" (Poole, 2011:49).

- Gerak langkah (footwork)

Gerak langkah atau footwork merupakan upaya mungubah posisi tubuh dengan gerak kaki. Menurut Aksan (2012:61), footwork(gerakan langkah kaki) merupakan dasar untuk bisa menghasilkan pukulan yang berkualitas, yaitu apabila dilakukan dalam posisi baik. Untuk bisa memukul dengan posisi baik, seorang pemain harus memiliki kecepatan gerak.Kecepatan gerak kaki tidak bisa dicapai kalau footwork-nya tidak teratur.

\section{- Teknik pukulan}

Untuk dapat bermain bulutangkis dengan baik, seorang pemain harus mampu melakukan beberapa teknik pukulan, mengacu pada pengklasifikasian yang dikemukakan oleh Husdarta (2010:21-22). Secara umum teknik pukulan dalam permainan bulutangkis dikategorikan ke dalam 3 jenis yaitu: (1) pukulan bawah, (2) pukulan lurus atau samping, (3) pukulan atas.

Teknik dasar dalam permainan bulutangkis terbagi atas beberapa macam teknik yaitu: (1) service (clear dan drop), (2) sidearm (drive, clear, dan smash), (3) overhead (clear dan drop), (4) clear, drop, dan smash, (5) need round the overhead forehand (clear, drop dan smash). Menurut Tohar (1992, dalam Syahriadi, 2014:316) macam-macam teknik pukulan yang harus dikuasai adalah: (1) pukulan servis, (2) pukulan lob, (3) pukulan drive, (4) pukulan dropshot, (5) pukulan pengembalian service, dan (6) pukulan smash.

Hal yang sama dikemukakan oleh Poole (2011:21-47), jenis pukulan dalam permainan bulutangkis dikelompokkan menjadi 5 macam yaitu: (a) pukulan service, pukulan service dapat dilakukan dengan 2 teknik antara lain, pukulan servis rendah atau (short service) dan pukulan servis lob tinggi (high lob service), (b) pukulan lob (clear), lob sebenarnya merupakan pukulan utama di dalam permainan single, dimana bola yang dalam (jauh dan belakang) dan memaksa lawan bertindak dari belakang hingga pukulan yang dihasilkan kurang membahayakan. Pukulan lob dapat dibedakan menjadi 3 macam yaitu lob tinggi ke belakang (devensive lob), lob serang (attacking lob), backhand lob atau overhead backhand flick lob, (c) pukulan smash, pukulan smash merupakan pukulan tercepat dan terkuat, dimana shuttlecock dipukul dengan kuat dan dihujamkan ke bawah di daerah-daerah yang kosong atau mengarah ke badan pemain lawan, smash ini dapat dilakukan dengan pukulan forehand maupun backhand, namun backhand overhead smash pada umumnya lebih sulit dilakukan hingga diperlukan didekat net atau sesekali dari belakang untuk mengejutkan lawan, (d) pukulan dropshot, dropshot adalah pukulan yang mengarahkan shuttlecock untuk dapat jatuh sedekat mungkin dengan net. Biasanya pukulan ini dilakukan dari belakang dengan menggunakan teknik pukulan overhead, (e) pukulan drive adalah pukulan mendatar dan cepat yang shuttlecocknya nyaris menyentuh net. Shuttlecock dipukul antara setinggi pinggang dan bahu, bahkan kadang-kadang lebih tinggi dari bahu hingga seperti pukulan smash. 
Ahmad Hasan Walinono, Meningkatkan Pembelajaran Pukulan Forehand Lob Bulutangkis Dengan Menggunakan Part And Whole Method Pada Peserta Didik Kelas Viii E Smpn 1 Winongan, Kabupaten Pasuruan

Terdapat beberapa teknik pukulan dalam permainan bulutangkis, salah satu diantaranya adalah teknik pukulan forehand lob. Menurut Zarwan (2009:34), dalam melakukan teknik pukulan forehand lob bulutangkis yang benar dibagi menjadi 3 tahapan yaitu: (a) Sikap awal meliputi:berdiri dengan sikap kaki kiri di depan dan kaki kanan di belakang dan kaki kangkang kirakira selebar bahu,berat badan pada kaki belakang bahu kiri menghadap ke net,tangan kiri diangkat seperti menjangkau sesuatu dan tangan kanan yang memegang raket diangkat lebih kurang setinggi bahu dan siku dibengkokkan sedikit, pandangan ke arah shuttlecock yang datang, (b) sikap pelaksanaan meliputi:tarik tangan kanan ke bawah dan diikuti dengan memukul shuttlecock setinggi mungkin, pindahkan titik berat badan pada kaki depan saat melakukan pukulan dan diikuti dengan memutar pinggang ke depan sehingga badan sepenuhnya menghadap ke depan (ke net), (c) sikap akhir adalah setelah pelaksanaan pukulan berakhir, maka gerakan tangan jangan dilawan biarkan ia mengikuti gerakan akhir raket. Kemudian posisi kaki yang di belakang dipindahkan ke depan, dan ambil posisi siap untuk melakukan pukulan berikutnya.

Pada tanggal 12 Agustus 2014, peneliti melakukan observasi awal di kelas VIII E SMP Negeri 1 Winongan Kabupaten Pasuruan dengan materi pembelajaran bulutangkis pukulan forehand lob. Setelah proses pembelajaran selesai, peneliti berdiskusi dengan pendidik mata pelajaran pendidikan jasmani olahraga dan kesehatan tentang pembelajaran bulutangkis pukulan forehand lob yang telah dilakukan, didapat keterangan bahwa terdapat permasalahan yang timbul yaitu keterampilan pukulan forehand lob bulutangkis yang masih rendah. Oleh sebab itu peneliti tertarik untuk melakukan penelitian pada kelas VIII E SMPN 1 Winongan Kabupaten Pasuruan.

Data observasi awal yang peneliti lakukan pada pelaksanaan pembelajaran pendidikan jasmani olahraga dan kesehatan dengan materi bulutangkis pukulan forehand lob pada peserta didik kelas VIII E SMP Negeri 1 Winongan Kabupaten Pasuruan, terdapat 37 peserta didik yang terdiri dari 30 peserta didik laki-laki dan 7 peserta didik perempuan dan diperoleh temuan data sebagai berikut: (1) Saat proses pembelajaran, terdapat 3 peserta didik lakilaki dan 1 peserta didik perempuan tidak membawa raket pada saat berada di lapangan, peserta didik yang berbaris di belakang kurang memperhatikan atau bergurau sendiri dengan teman yang ada di sampingnya saat pendidik menyampaikan materi pembelajaran, (2) Setelah pemanasan, pendidik menyampaikan materi tentang teknik dasar permainan bulutangkis (forehand lob), setelah itu pendidik memberikan contoh teknik pukulan forehand lob secara global, lalu peserta didik di bagi menjadi formasi kelompok setelah itu peserta didik diberikan kebebasan bermain bulutangkis secara bergantian. Hal tersebut menjadikan proses pembelajaran menjadi tidak fokus pada materi pembelajaran karena materi pokok yang disampaikan adalah pukulan forehand lob bulutangkis, dan apabila peserta didik diberikan kebebasan bermain tidak menutup kemungkinan peserta didik juga melakukan teknik pukulan yang lain seperti drive, smash dan lain-lain, (3) Sejumlah 15 peserta didik (40,54\%) belum bisa melakukan teknik memegang raket (Grips) pukulan forehand lob dengan benar, (4) sejumlah 17 peserta didik (45, $94 \%$ ) pada sikap awal saat melakukan teknik pukulan forehand lob masih belum benar, (5) sejumlah 17 peserta didik (45,94\%) pada sikap saat melakukan pukulan forehand lob masih belum benar, (6) sejumlah 18 peserta didik $(48,64 \%)$ pada sikap akhir saat melakukan teknik pukulan forehand lob masih belum benar, (7) sejumlah 25 peserta didik $(67,56 \%)$ arah shuttlecock masih salah setelah dipukul.

Berdasarkan temuan hasil data observasi awal, maka dapat ditarik kesimpulan bahwa masih ditemukannya beberapa peserta didik yang masih belum dapat menguasai teknik dasar permainan bulutangkis yaitu pukulan forehand lob. Hal ini dikarenakan karena penerapan metode pembelajaran yang diberikan oleh pendidik saat proses pembelajaran pukulan forehand lob bulutangkis kurang efektif sehingga berpengaruh terhadap pencapaian hasil belajar yang diperoleh peserta didik kurang maksimal.

\section{METODE}


Penelitian ini adalah Penelitian Tindakan Kelas (classroom action research). Penelitian Tindakan Kelas (PTK) merupakan penelitian yang bertujuan untuk menyelesaikan permasalahan yang dihadapi pendidik dan meningkatkan kualitas praktik pembelajaran di kelas. Penelitian Tindakan Kelas (PTK) memiliki beberapa tahapan pelaksanaan yaitu: (1) perencanaan, (2) pelaksanaan, (3) pengamatan, dan (4) refleksi (Arikunto, 2010:131). Penelitian Tindakan Kelas (PTK) memiliki beberapa siklus. Apabila hasil dari kegiatan yang dilakukan pada siklus I kurang sesuai dengan kriteria yang telah ditetapkan maka akan dilanjutkan ke siklus II dengan cara melakukan perbaikan pada tahapan perencanaan.

Kemmis \& Mc Taggart dalam Winarno, (2011:73) menjelaskan bahwa prosedur atau langkah-langkah yang diperlukan pada Penelitian Tindakan Kelas (PTK) ini yaitu; (1) mengidentifikasi suatu masalah, hal ini dilakukan berdasarkan pada hasil observasi peneliti terhadap proses pembelajaran dengan materi pukulan forehand lob bulutangkis yang telah dilakukan, (2) merumuskan suatu masalah, yaitu dirumus-kan sendiri oleh peneliti setelah mengetahui masalah yang terjadi pada saat proses pembelajaran pada materi pukulan forehand lob bulutangkis yang telah dilakukan, (3) melakukan penyusunan rencana tindakan (siklus I), (4) melakukan tindakan pada proses pembelajaran dengan tahapantahapan menggunakan part and whole method, dalam hal ini juga dilakukan observasi terhadap pelaksanaan pembelajaran tersebut oleh peneliti, (5) melakukan refleksi dari tindakan pelaksanaan pembelajaran yang telah dilakukan oleh peneliti, (6) berdasarkan hasil observasi dan refleksi yang telah dilakukan, apabila ditemukan kelemahan atau kekurangan yang terjadi, maka perlu dilakukan revisi dalam perencanaan, (7) penyusunan rencana revisi perencanaan (siklus II) dilanjutkan sampai hasil analisis observasi sudah sesuai dengan harapan yang akan dicapai.

Pada penelitian ini, peneliti mengumpulkan data melalui observasi catatan lapangan dan dokumentasi. Saat melakukan observasi, peneliti menggunakan pedoman dalam melakukan pengamatan dan penilaian terhadap gerakan pukulan forehand lob bulutangkis yang dilakukan peserta didik. Peneliti memperhatikan dan menilai tentang teknik pegangan raket, sikap siap, sikap lengan, sikap kaki, arah shuttlecock.

Setelah semua data terkumpul kemudian menganalisis data yang telah diperoleh, sehingga berdasarkan data-data tersebut dapat ditarik suatu kesimpulan dengan menggunakan teknik analisis data deskriptif, sedangkan perhitungan angka kuesioner menggunakan teknik persentase dengan rumus sebagai berikut:

$$
\begin{aligned}
& p=\frac{f}{N} \times 100 \% \\
& \text { Keterangan: } \\
& \mathrm{f}=\text { jumlah / frekuensi } \\
& \mathrm{N}=\text { banyaknya subjek/individu } \\
& \mathrm{P}=\text { angka persentase (Sudijono, } \\
& \quad 2001: 40)
\end{aligned}
$$

Sebagai patokan terhadap hasil analisis persentase digunakan klasifikasi yang dijelaskan pada tabel berikut ini,

Tabel 1. Persentase taraf keberhasilan tindakan

\begin{tabular}{cll}
\hline No & Persentase & Kategori \\
\hline \hline $\mathbf{1}$ & $75,01 \%-100 \%$ & Sangat valid \\
$\mathbf{2}$ & $50,01 \%-75 \%$ & Cukup valid \\
$\mathbf{3}$ & $25,01 \%-50 \%$ & Tidak valid \\
$\mathbf{4}$ & $00,00 \%-25 \%$ & Sangat tidak valid \\
\hline \multicolumn{2}{l}{ Sumber: (Akbar dan Sriwiyana, 2010:212). }
\end{tabular}

Kehadiran peneliti pada penelitian ini bertindak sebagai pendidik mata pelajaran pendidikan jasmani olahraga dan kesehatan. Peneliti bekerjasama atau berkolaborasi dengan pengamat dalam menyusun konsep tindakan yang akan dilakukan. Tindakan yang akan dilakukan meliputi penerapan part and whole method (metode bagian-keseluruhan) pada proses pembelajaran dengan materi bulutangkis pukulan forehand lob.

\section{HASIL}

Penelitian ini dilaksanakan dalam dua siklus. Hasil penelitian dideskripsikan dalam paparan hasil penelitian siklus I dan hasil penelitian siklus II. 
Ahmad Hasan Walinono, Meningkatkan Pembelajaran Pukulan Forehand Lob Bulutangkis Dengan Menggunakan Part And Whole Method Pada Peserta Didik Kelas Viii E Smpn 1 Winongan, Kabupaten Pasuruan

\section{Hasil penelitian siklus I}

Pada pelaksanaan pembelajaran pukulan forehand lob bulutangkis dengan menggunakan part and whole metod method (metode bagian-keseluruhan)pada siklus I yang dilakukan oleh peneliti dengan di bantu pengamat dan dilaksanakan selama 3 kali pertemuan. Meskipun Hasil yang didapat pada pelaksanaan pembelajaran pukulan forehand lob bulutangkis yang telah dilaksanakan pada siklus I terdapat peningkatan, peningkatan tersebut masih belum maksimal dan diperlukan perbaikan pada hasil belajar peserta didik

Adapun hasil dari pembelajaran pukulan forehand lob bulutangkis dapat di lihat pada tabel persentase sebagai berikut:

Tabel 2. Persentase pukulan forehand lob bulutangkis pada siklus I yang diikuti sejumlah 37 peserta didik.

\begin{tabular}{clccl}
\hline \multirow{2}{*}{ No } & \multirow{2}{*}{ Keterampilan } & \multicolumn{2}{c}{ Siklus 1 } & \multirow{2}{*}{ Kategori } \\
\cline { 3 - 4 } & & $\mathbf{f}$ & $\%$ & \\
\hline 1 & Pegangan raket & 30 & $81 \%$ & Valid \\
2 & Sikap siap & 28 & $75,6 \%$ & Valid \\
3 & Sikap lengan & 26 & $70,2 \%$ & Cukup valid \\
4 & Sikap kaki & 27 & $70,2 \%$ & Cukup valid \\
5 & Arah shuttlecock & 25 & $67,5 \%$ & Cukup valid \\
\hline
\end{tabular}

Setelah proses pembelajaran pukulan forehand lob bulutangkis menggunakan part and whole method (metode bagian-keseluruhan) pada peserta didik kelas VIII E SMPN 1 Winongan Kabupaten Pasuruan siklus I dilaksanakan, diperoleh hasil data sebagai berikut: sejumlah 30 peserta didik atau $(81 \%)$ sudah mempraktikkan dengan benar pada aspek pegangan raket, 28 peserta didik atau $(75,6 \%)$ sudah mempraktikkan dengan benar pada aspek sikap siap, 26 peserta didik atau $(70,2 \%)$ sudah mempraktikkan dengan benar pada aspek sikap lengan, 27 peserta didik atau (72,9\%) sudah mempraktikkan dengan benar pada aspek sikap kaki, 25 peserta didik atau $(67,5 \%)$ sudah mempraktikkan dengan benar pada aspek arah shuttlecock.

\section{Hasil penelitian siklus II}

Siklus II ini merupakan perbaikan dari perencanaan yang telah dilaksanakan pada siklus I, adapun harapan yang peneliti ingin didapatkan adalah: (1) tingkat kesalahan yang dilakukan peserta didik pada siklus I tidak terulang kembali pada siklus II, (2) terdapat peningkatan keterampilan pada peserta didik dibuktikan melalui ketuntasan hasil belajar pukulan forehand lob bulutangkis pada peserta didik yang cukup berarti pada siklus II. Kegiatan pembelajaran pukulan forehand lob bulutangkis pada siklus II ini tetap menggunakan metode yang sama pada siklus I yaitu dengan menggunakan part and whole method (metode bagiankeseluruhan). Peserta didik pada saat melakukan teknik gerakan pukulan forehand lob bulutangkis diberikan latihan secara berulang-ulang hanya kepada peserta didik yang belum mengusai gerakan tertentu dengan pendampingan peneliti dan pengamat secara lebih intensif. Setelah melakukan gerakan bagian dirasa cukup tindakan berikutnya yang diberikan adalah latihan gerakan keseluruhan melakukan gerakan pukulan forehand lob bulutangkis, tujuan dari latihan gerakan yang akan dilaksanakan pada siklus II ini peserta didik mampu melatih kemampuan peserta didik dalam melakukan pukulan forehand lob bulutangkis sehingga hasil belajar peserta didik meningkat dan peserta didik mampu mencapai Standar Ketuntasan Minimal (SKM) yang telah ditetapkan.

Tabel 3. Persentase pukulan forehand lob bulutangkis pada siklus II yang diikuti sejumlah 37 peserta didik.

\begin{tabular}{clccc}
\multirow{2}{*}{ No } & \multirow{2}{*}{ Keterampilan } & \multicolumn{2}{c}{ Siklus 1 } & \multirow{2}{*}{ Kategori } \\
\cline { 3 - 4 } & & $\mathbf{f}$ & $\%$ & \\
\hline 1 & Pegangan raket & 34 & $91,8 \%$ & \\
2 & Sikap siap & 32 & $86,4 \%$ & Valid \\
3 & Sikap lengan & 33 & $89,1 \%$ & Valid \\
4 & Sikap kaki & 32 & $86,4 \%$ & Valid \\
5 & Arah shuttlecock & 31 & $89,1 \%$ & Valid \\
\hline
\end{tabular}

Setelah proses pembelajaran pukulan forehand lob bulutangkis menggunakan part and whole method (metode bagian-keseluruhan) pada peserta didik kelas VIII E SMPN 1 Winongan Kabupaten Pasuruan dilaksanakan, diperoleh hasil data sebagai berikut: sejumlah 34 peserta didik atau $(91,8 \%)$ sudah mempraktikkan dengan benar pada aspek pegangan raket, 32 peserta didik atau $(86,4 \%)$ sudah mempraktikkan dengan benar pada aspek sikap siap, 33 peserta didik atau $(89,1 \%)$ sudah mempraktikkan dengan benar pada aspek sikap lengan, 32 peserta didik atau (86,4\%) sudah mempraktikkan dengan benar pada 
aspek sikap kaki, 31 peserta didik atau $(83,7 \%)$ sudah mempraktikkan dengan benar pada aspek arah shuttlecock.

\section{PEMBAHASAN}

\section{Siklus I}

Dwiyogo (2010:129) mengatakan bahwa "pendidikan jasmani olahraga dan kesehatan merupakan bagian integral dari pendidikan yang bertujuan untuk mengembangkan kebugaran jasmani, melatih keterampilan gerak, berfikir kritis, keterampilan sosial, penalaran, stabilitas emosional, tindakan moral, dan kemudian aspek hidup sehat".

Setelah penerapan part and whole method (metode bagian-keseluruhan) pada proses pembelajaran pukulan forehand lob bulutangkis, pada siklus I terdapat peningkatan hasil keterampilan pada peserta didik kelas VIII E SMPN 1 Winongan Kabupaten Pasuruan. Hal ini terlihat pada perbandingan hasil pencapaian peserta didik kelas VIII E SMPN 1 Winongan kabupaten Pasuruan sebelum dan sesudah diterapkannya part and whole method (metode bagian-keseluruhan). Tingkat kesalahan peserta didik sebelum diterapkannya tindakan yang cukup tinggi, (1) pada indikator teknik memegang raket (grips) terdapat sejumlah 15 peserta didik atau $(40,5 \%)$, (2) pada indikator sikap awal melakukan pukulan terdapat sejumlah 17 peserta didik atau $(45,9 \%)$, (3) pada indikator sikap saat melakukan pukulan terdapat sejumlah 17 peserta didik atau $(45,9 \%),(4)$ pada indikator sikap akhir sikap akhir terdapat sejumlah 18 peserta didik atau (48,6\%), (5) pada indikator arah shuttlecock setelah melakukan pukulan terdapat sejumlah 25 peserta didik atau $(67,5 \%)$. Setelah diterapkannya tindakan pada siklus I persentase tingkat keberhasilan peserta didik kelas VIII E SMPN 1 Winongan Kabupaten Pasuruan banyak mengalami peningkatan. Persentase tingkat keberhasilan peserta didik pada aspek sikap pegangan raket peserta didik yang mampu mempraktikkan dengan benar terdapat sejumlah 30 peserta didik atau (81\%), pada aspek sikap siap, peserta didik yang mampu mempraktikkan dengan benar terdapat sejumlah 28 peserta didik atau (75,5\%), pada aspek sikap lengan, peserta didik yang mampu mempraktikkan dengan benar terdapat sejumlah 26 peserta didik atau (70,2\%), pada aspek sikap kaki peserta didik yang mampu mempraktikkan dengan benar terdapat sejumlah 27 peserta didik atau $(72,9 \%)$ sedangkan pada aspek arah shuttlecock peserta didik yang mampu mempraktikkan dengan benar terdapat sejumlah 25 peserta didik atau $(67,5 \%)$.

Sedangkan peserta didik yang masih belum benar saat melakukan pukulan forehand lob bulutangkis pada siklus I diperoleh data sebagai berikut: (1) pada aspek sikap pegangan raket, peserta didik yang masih salah saat melakukan teknik pukulan forehand lob bulutangkis sejumlah 7 peserta didik (18,9\%), (2) pada aspek sikap siap, peserta didik yang masih salah saat melakukan teknik pukulan forehand lob bulutangkis sejumlah 9 peserta didik (24,3\%), (3) pada aspek sikap lengan, peserta didik yang masih salah saat melakukan teknik pukulan forehand lob bulutangkis sejumlah 11 peserta didik (29,7\%), (4) pada aspek sikap kaki, peserta didik yang masih salah saat melakukan teknik pukulan forehand lob bulutangkis sejumlah 10 peserta didik (27\%), (5) pada aspek arah shuttlecock, peserta didik yang masih salah saat melakukan teknik pukulan forehand lob bulutangkis sejumlah 12 peserta didik (32,4\%), Melihat dari hasil pembelajaran pada peserta didik siklus I di atas diketahui bahwa peserta didik sudah mengalami peningkatan dalam hal keterampilan melakukan pukulan forehand lob bulutangkis, akan tetapi masih diperlukan tindakan pada siklus II dengan harapan kesalahan yang dilakukan peserta didik pada siklus I dapat tidak diulangi peserta didik pada siklus yang ke II.

Mencermati hal tersebut, peningkatan keterampilan pukulan forehand lob bulutangkis pada peserta didik kelas VIII E SMPN 1 Winongan Kabupaten Pasuruan dikarenakan oleh penerapan part and whole method (metode bagian-keseluruhan) pada proses pembelajaran pukulan forehand lob bulutangkis. Metode ini sesuai pada materi pembelajaran teknik dasar dan memudahkan peserta didik dalam menerima pembelajaran gerak karena gerakan yang kompleks dipecah menjadi bagian-perbagian gerak yang lebih sederhana. Hal yang sama dikemukan oleh Widijoto (2010:11), part and 
Ahmad Hasan Walinono, Meningkatkan Pembelajaran Pukulan Forehand Lob Bulutangkis Dengan Menggunakan Part And Whole Method Pada Peserta Didik Kelas Viii E Smpn 1 Winongan, Kabupaten Pasuruan

whole merupakan "pendekatan motor learning yang mengajarkan aktivitas jasmani berdasarkan klasifikasi keterampilan dan teori proses informasi yang diterima, part and whole akan sesuai dengan proses pembelajaran teknik dasar yaitu bagianbagian dari teknik hingga teknik keseluruhan".

Akan tetapi peningkatan hasil keterampilan peserta didik kelas VIII E SMPN 1 Winongan Kabupaten Pasuruan saat melakukan pukulan forehand lob bulutangkis pada siklus I belum mencapai target yang ingin dicapai. Oleh sebab itu penelitian akan diteruskan pada siklus II untuk memperoleh peningkatan hasil keterampilan yang lebih baik pada peserta didik kelas VIII E SMPN 1 Winongan Kabupaten Pasuruan saat melakukan pukulan forehand lob bulutangkis.

\section{Siklus II}

Siklus II ini merupakan perbaikan dari perencanaan yang telah dilaksanakan pada siklus II, adapun harapan yang peneliti ingin dapatkan adalah: (1) tingkat kesalahan yang dilakukan peserta didik pada siklus I tidak terulang kembali pada siklus II, (2) terdapat peningkatan keterampilan pada peserta didik dibuktikan melalui ketuntasan hasil belajar pukulan forehand lob bulutangkis pada peserta didik yang cukup berarti pada siklus II. Kegiatan pembelajaran pukulan forehand lob bulutangkis pada siklus II ini tetap menggunakan metode yang sama pada siklus I yaitu dengan menggunakan part and whole method (metode bagian-keseluruhan). Peserta didik pada saat melakukan teknik gerakan pukulan forehand lob bulutangkis diberikan latihan secara berulang-ulang hanya kepada peserta didik yang belum mengusai gerakan tertentu dengan pendampingan peneliti dan pengamat secara lebih intensif. Setelah melakukan gerakan bagian dirasa cukup tindakan berikutnya yang diberikan adalah latihan gerakan keseluruhan melakukan gerakan pukulan forehand lob bulutangkis, tujuan dari latihan gerakan yang akan dilaksanakan pada siklus II ini peserta didik mampu melatih kemampuan peserta didik dalam melakukan pukulan forehand lob bulutangkis sehingga hasil belajar peserta didik meningkat dan peserta didik mampu mencapai Standar Ketuntasan Minimal (SKM) yang telah ditetapkan.
Proses pembelajaran pukulan forehand lob bulutangkis dengan menggunakan pukulan part and whole method (metode bagian-keseluruhan) pada siklus II ini peneliti dibantu pengamat berusaha memberikan bimbingan lebih intensif lagi, terutama terhadap peserta didik yang belum bisa mempraktikkan sikap gerak pukulan forehand lob bulutangkis dengan benar. Pada proses pembelajaran, peneliti memberikan tugas kepada peserta didik untuk melakukan gerakan yang belum dikuasai secara berulang-ulang. Setelah peserta didik menguasai gerakan-gerakan tersebut, peneliti menyuruh peserta didik untuk mempraktikkan gerakan pukulan forehand lob bulutangkis secara keseluruhan. Dengan melakukan latihan gerakan pukulan forehand lob bulutangkis secara berulang-ulang dapat meningkatkan keterampilan gerak pada peserta didik kelas VIII E SMPN 1 Winongan Kabupaten Pasuruan. Pada siklus II juga terdapat peningkatan hasil keterampilan pada peserta didik kelas VIII E SMPN 1 Winongan Kabupaten Pasuruan. Terlihat pada persentase keberhasilan peserta didik melakukan pukulan forehand lob bulutangkis pada siklus II adalah sebagai berikut: (1) pada aspek sikap pegangan raket peserta yang mampu mempraktikkan dengan benar terdapat sejumlah 34 peserta didik atau $(91,8 \%)$, (2) pada aspek sikap siap peserta didik yang mampu mempraktikkan dengan benar terdapat sejumlah 32 peserta didik atau $(86,4 \%)$, (3) pada aspek sikap lengan peserta didik yang mampu mempraktikkan dengan benar terdapat sejumlah 33 peserta didik atau (89,1\%), (4) pada aspek sikap kaki peserta didik yang mampu mempraktikkan dengan benar terdapat sejumlah 32 peserta didik atau $(86,4 \%)$ sedangkan (5) pada aspek arah shuttlecock peserta didik yang mampu mempraktikkan dengan benar terdapat sejumlah 31 peserta didik atau $(83,7 \%)$.

Sedangkan peserta didik yang masih belum benar saat melakukan pukulan forehand lob bulutangkis pada siklus I diperoleh data sebagai berikut: Setelah proses pembelajaran pukulan forehand lob bulutangkis menggunakan part and whole method (metode bagian-keseluruhan) pada peserta didik kelas VIII E SMPN 1 Winongan Kabupaten Pasuruan dilaksanakan, diperoleh hasil data sebagai berikut: (1) pada 
aspek sikap pegangan raket, peserta didik yang masih salah saat melakukan teknik pukulan forehand lob bulutangkis sejumlah 3 peserta didik $(8,1 \%)$, (2) pada aspek sikap siap, peserta didik yang masih salah saat melakukan teknik pukulan forehand lob bulutangkis sejumlah 5 peserta didik $(13,5 \%)$, (3) pada aspek sikap lengan, peserta didik yang masih salah saat melakukan teknik pukulan forehand lob bulutangkis sejumlah 4 peserta didik $(10,8 \%)$, (4) pada aspek sikap kaki, peserta didik yang masih salah saat melakukan teknik pukulan forehand lob bulutangkis sejumlah 5 peserta didik (13,5\%), (5) pada aspek arah shuttlecock, peserta didik yang masih salah saat melakukan teknik pukulan forehand lob bulutangkis sejumlah 6 peserta didik $(16,2 \%)$. Melihat dari hasil pembelajaran peserta didik pada siklus II di atas diketahui keterampilan peserta didik kelas VIII E SMPN 1 Winongan Kabupaten Pasuruan mengalami peningkatan dengan persentase keberhasilan yang peniliti harapkan.

\section{KESIMPULAN}

Setelah pelaksanaan Penelitian Tindakan Kelas (PTK) ini, penerapan part and whole method (metode bagian-keseluruhan) dapat meningkatkan keterampilan pukulan forehand lob bulutangkis pada peserta didik kelas VIII E SMP Negeri 1 Winongan Kabupaten Pasuruan. Peningkatan tersebut dapat dilihat pada ketuntasan hasil belajar peserta didik dengan materi pembelajaran pukulan forehand lob bulutangkis yang telah dilaksanakan,

\section{SARAN}

Terkait hasil Penelitian Tindakan Kelas (PTK) pada upaya peningkatan keterampilan pukulan forehand lob bulutangkis pada peserta didik kelas VIII E SMP Negeri 1 Winongan Kabupaten Pasuruan melalui penerapan part and whole method (metode bagian-keseluruhan) yang telah dilaksanakan, Penelitian Tindakan Kelas (PTK) ini dapat dijadikan sebagai sumber referensi untuk memperkaya pengetahuan pendidik mata pelajaran pendidikan jasmani, olahraga dan kesehatan dalam mengajar.

Setelah penelitian ini dilaksanakan, hasil dari penelitian ini diharapkan dapat dijadikan sebagai sumber rujukan bagi mahasiswa lain yang akan melakukan penelitian di kemudian hari.

\section{DAFTAR RUJUKAN}

Akbar, dkk. 2010. Penelitian Tindakan Kelas. Malang: Surya Press Gemilang.

Aksan, H. 2012. Mahir Bulutangkis. Bandung: Nuansa Cendekia.

Alhusin, 2007.Gemar Bermain Bulutangkis. Surakarta: CV. Seti-aji.

Arikunto. S. 2010. Prosedur Penelitian Suatu Pendekatan Praktik. Jakarta: Rineka Cipta.

BNSP. 2006. Standar Isi Sekolah Dasar/ Madrasah Ibtidaiyah: Departemen Pendidikan Nasional.

Dwiyogo,W. 2010. Penelitian Keolahragaan. Malang: Universitas Negeri Malang (UM Press).

Husdarta, J. 2010. Pendidikan Jasmani Olahraga dan Kesehatan. Jakarta: Pusat Pembukuan Kementrian Pendidikan Nasional.

Poole. J. 2011. Belajar Bulu Tangkis. Bandung: Pionir Jaya.

Yogesh, 2011, Effects of different feedback methods on badminton skills learning. Journal of Physical Education and Sport.Volume 11, Nomor 3, 2011.

Susanto, 2006. Perbedaan Hasil Penempatan Shuttlecock Dengan Servis Backhand Pendek.Jurnal Anatomi Indonesia.Volume 01.Nomor 01, 2006.

Syahriadi.2014. Pengaruh Latihan Pliometrik dan Latihan Beban terhadap Jumping Smash Atlet Bulutangkis.Jurnal 
Ahmad Hasan Walinono, Meningkatkan Pembelajaran Pukulan Forehand Lob Bulutangkis Dengan Menggunakan

IPTEK Olahraga.Volume 16, Nomor 3, 2014.

UNESCO. Pengertian pendidikan jasmani (Online), (www.agiliaalunjati.blogspot.com/201 2/11/pendidikan-jasmani-danolahraga.html). Diakses pada tanggal 10 januari 2015.

Widijoto, H. 2010. Strategi Pembelajaran Pendidikan Jasmani Olahraga dan Kesehatan. Malang: UPT PP. Universitas Negeri Malang.

Winarno. 1990. Pendidikan Jasmani Kajian Teori, Praktik Pendidikan Dan Pembelajaran. Malang: PSSJ Pendidikan dan Olahraga FIP IKIP.

Winarno. 2011. Metodologi Penelitian Dalam Pendidikan Jasmani. Malang: Media Cakrawala Utama Press.

Zarwan, 2009. Bulutangkis Dasar. Padang: Wineka Media. 